\title{
Intraparenchymal chordoid Meningioma After Radiotherapy for Hodgkin Lymphoma: A Case Report and Review of the Literature
}

\author{
Mustafa Efendioglu1, Recep Basaran', Dogan Gundogan², Fatih Han Bolukbası ${ }^{3}$, \\ Mustafa Kaksi ${ }^{4}$, Aydin Sav ${ }^{5,}$ and Tuncay Kaner ${ }^{2}$ \\ ${ }^{1}$ Dr. Lutfi Kirdar Kartal Training and Research Hospital, Department of Neurosurgery, Istanbul, Turkey \\ ${ }^{2}$ Istanbul Medeniyet University Goztepe Education and Research Hospital, Department of Neurosurgery, \\ Istanbul, Turkey \\ ${ }^{3}$ Medipol University School of Medicine, Department of Neurosurgery, Istanbul, Turkey \\ ${ }^{4}$ Yalova Hospital, Department of Neurosurgery, Yalova, Turkey \\ ${ }^{5}$ Acibadem University School of Medicine Department of Pathology, Istanbul, Turkey
}

\begin{abstract}
Objective: Hodgkin lymphoma can be treated by radiotherapy or chemotherapy alone or combined. Meningiomas account for $1-4.2 \%$ of all primary intracranial tumors in children, and chordoid meningioma is a very rare subtype. In this study, we investigated a case of an intraparenchymal chordoid meningioma that developed during the early stage in a patient with Hodgkin lymphoma who had been treated with radiotherapy.

Case: A 10-year-old male patient was diagnosed with Hodgkin lymphoma and was treated with a combination of radiotherapy and chemotherapy. He presented at our emergency service 6 years later. He had a fever and was suffering from discomfort and insignificant left hemiparesis (4/5). Contrast-enhanced cranial magnetic resonance imaging (MRI) showed a mass in the right temporoparietal region. The intracranial lesion was surgically excised. The tumor was identified as a $\mathrm{WHO}$ grade 2 chordoid meningioma by the pathological examination. The Ki-67 proliferation index was found to be $20-25 \%$.

Conclusion: Surgeons must remember that radiation-associated meningiomas may occur in the early stage of the treatment as well as in the late stage. Young patients with grade 2 chordoid meningiomas must be followed-up in case of recurrence, and tumors with high Ki-67 indexes are highly expected to relapse.
\end{abstract}

Keywords: Meningioma, Hodgkin lymphoma, radiation, secondary tumor, chordoid, intraparenchymal.

\section{INTRODUCTION}

Hodgkin lymphoma (HL) accounts for $1 \%$ of all carcinomas and $25-40 \%$ of lymphomas [1-5]. HL is common in males at all ages and peaks between the ages of 20 and 40 years [3, 6].

$\mathrm{HL}$ is classified by WHO grading [7]. The most common type in Turkey and developing countries is the mixed cellular type of $\mathrm{HL}$ [8].

Both chemotherapy (KT) and radiotherapy (RT) are effective methods for the treatment of Hodgkin lymphoma. Therefore, RT and KT alone or in combination can be applied [9-12].

Many of the complications that occur during the late stage after the treatment of Hodgkin lymphoma are associated with radiotherapy. The annual rate of secondary malignancy is approximately $1 \%[13,14]$. Despite this low rate, the secondary malignancies are

*Address correspondence to this author at the Department of Pathology, Acibadem University School of Medicine, Istanbul, Turkey; Tel: +90 53232155 68; Fax: +90 21637753 57; E-mail: murataydinsav@gmail.com the primary cause of mortality and morbidity in patients with HL $[15,16]$.

Meningioma is very rare in children. It accounts for $1-4.2 \%$ of all primary intracranial tumors during childhood [17-28]. Intraparenchymal or subcortical meningiomas without dural connections are even rarer [29].

Chordoid meningiomas accounts for only $0.5-1 \%$ of all meningiomas [30]. As with all meningiomas, chordoid meningiomas are generally more common in adults and are very rare in children [26, 31]. The development of a radiation-associated meningioma is rare and occurs long after radiation treatment [32, 33]. $A$ radiation-associated cerebral meningioma, which is a very rare complication of leukemia treatment, has been reported [19, 20, 29, 34, 35]; however, only one case of cerebral meningioma after Hodgkin lymphoma treatment has been reported [36]. Posterior fossa meningioma, which is a type of meningothelial tumor, was also found.

In this article, we present the case of a patient who received radiotherapy for the treatment of Hodgkin 
lymphoma and was later diagnosed with a supratentorial meningioma during the early stage after treatment.

\section{CASE REPORT}

A 10-year-old male patient was examined in 2006 because of a nodule in his neck. He was diagnosed with mixed-cell, stage 4A classic Hodgkin lymphoma. The patient was treated with a combination of radiotherapy at $180 \mathrm{cGy} / \mathrm{fr} 25$ Gy and 6 courses of ABVD chemotherapy in his bilateral neck and mediastinum. He was diagnosed with anemia prior to chemotherapy, and his hemoglobin level increased after treatment. The follow-up of the patient was performed for two years but was then terminated. The patient had no complaints within that period and then presented at the emergency service 6 years after the termination of radiotherapy. He had fever, impaired general condition and weakness on the left side. No pathological findings were detected in the physical examination except for insignificant left hemiparesis $(4 / 5)$. The blood tests revealed only anemia. The patient had a resistant fever. PET and CT scans were repeated, and a slightly hypermetabolic mass with intense edema was observed in the right parietal space. In addition, a decrease in the metabolism of the right cerebral cortex was observed compared with its left-side counterpart. Contrast-enhanced cranial magnetic resonance imaging (MRI) revealed a mass with maximum dimensions of $49 \times 41 \times 39 \mathrm{~mm}$ located in the right temporoparietal region with significant pathological contrasting in the solid component (Figure
1). The doctors held a consultation and planned the surgical treatment.

\section{SURGERY}

A craniotomy was performed in the right temporoparietal region. The location of the mass was determined with sonography. We moved transcortically with bipolar coagulation and aspiration and reached a highly solid deeply located tumoral mass with cleavages in some areas. The tumoral tissue was tattletale gray, highly vascular and not adsorbable due to the numerous feeding arteries. The solid tumoral mass was totally excised with CUSA (cavitron ultrasonic surgical aspirator).

\section{HISTOPATHOLOGY}

Microscopic examination showed tumor consisting of tumor cells forming sheets in where the neoplastic cells demonstrate classic cytological features of meningothelium, i.e., round to oval nuclei, delicate chromatin, small solitary nucleoli, and frequent nuclearcytoplasmic invaginations and/or homogenization. In patchy areas of tumor, the tumor cells are largely uniform; with oval nuclei with delicate chromatin that on occasion show central clearing, or the formulation of cytoplasmic-nuclear inclusions mimicking arachnoidal cap cells. The invaginations, also termed pseudoinclusions, appear as round, circumscribed, and intranuclear areas surrounded by marginated chromatin. Another eye-catching feature was cords or trabeculae formed by eosinophilic, often vacuolated cells entrapped in an abundant extracellular mucoid

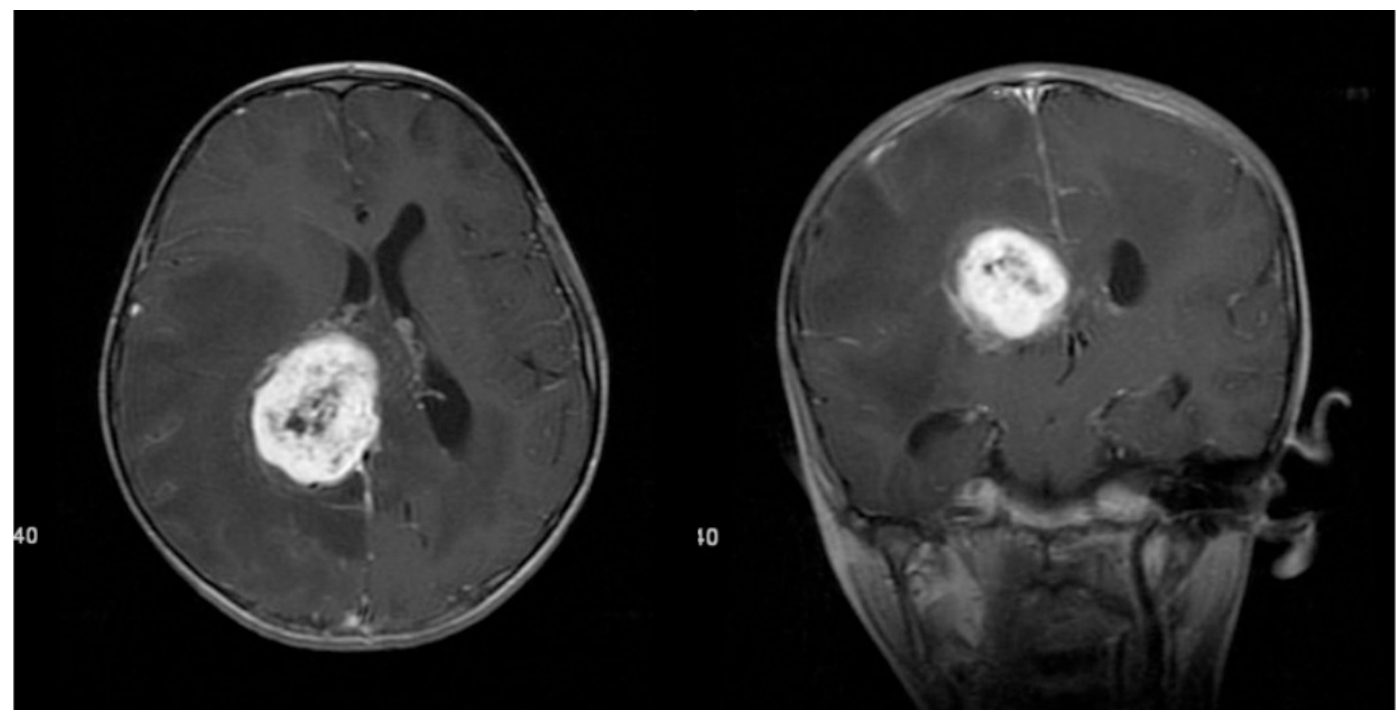

Figure 1: Preoperative MRI scan with contrast enhacement reveals a mass located on right temporoparietal area within deep white matter. It has pathological contrast enhacement on its solid component and centrally contains a cystic necrotic area. Prominent vasogenic oedema is found around the mass. 
matrix background. Although classic features of meningioma, such as whorls and psammoma bodies, are scant, if present at all, in examples with advanced chordoid features. There was an associated myxoid matrix forming pools and interspersing tumor cells giving rise to impression of chordoid features to the meningeal tumor (Figure 2).

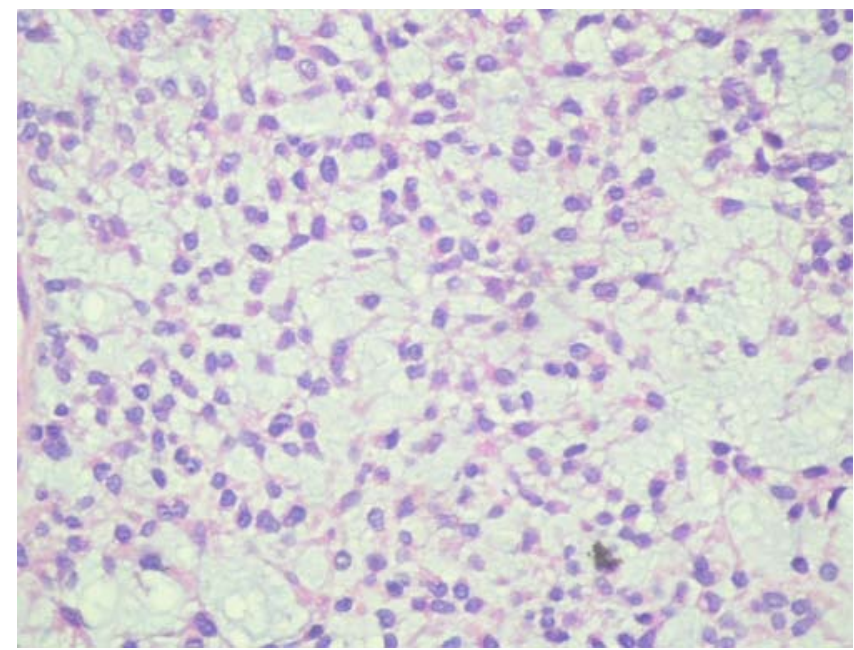

Figure 2: Monotonous meningothelial tumor cells floating in a myxoid matrix resembling chordoid features. (Hematotoxylin eosin; x400 original magnifiacation).

By using conventional histochemistry staining procedure, AS-AB identified acid mucopolysaccharides in the matrix consisting myxoid features (Figure 3).

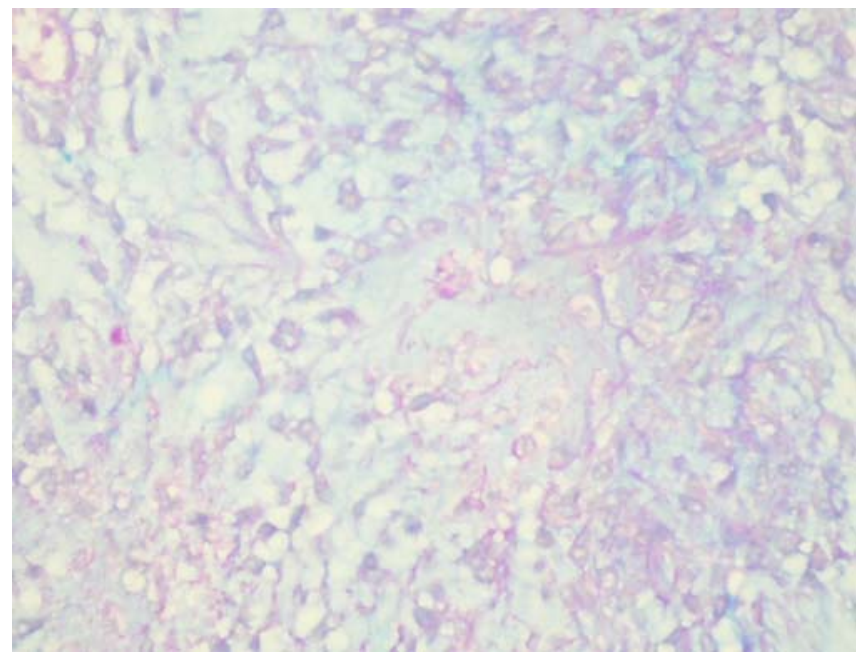

Figure 3: Diffuse acid mucopoliysaccharide material in between tumor cells. (Alcian blue- PAS; x400 original magnifiacation).

Immunochemistry revealed a variable immunoreactivity of tumors cells, i.e., membranous EMA (Figure 4), focal areas of cytoplasmic and nuclear S100, focal nuclear progesterone reactivity. No CD34and pancytokeratin immunoexpressivity was seen. Ki-67 (MIB-1) index was 10\% (Figure 5) and no p53 reactivity at all.

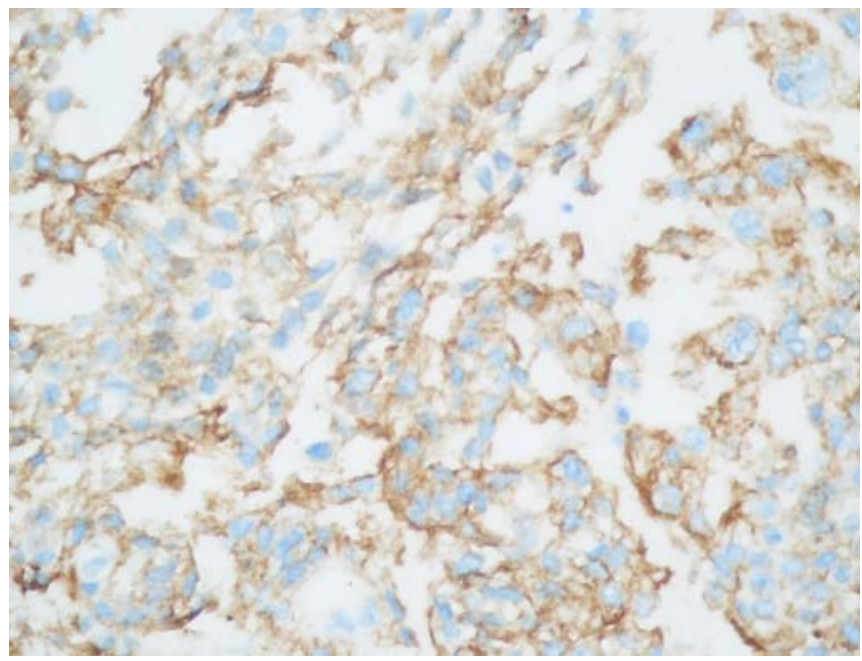

Figure 4: Almost all tumor cells showing membranous immunopositivity with (Streptavidin biotinylated complement; EMA; $x 400$ original magnification).

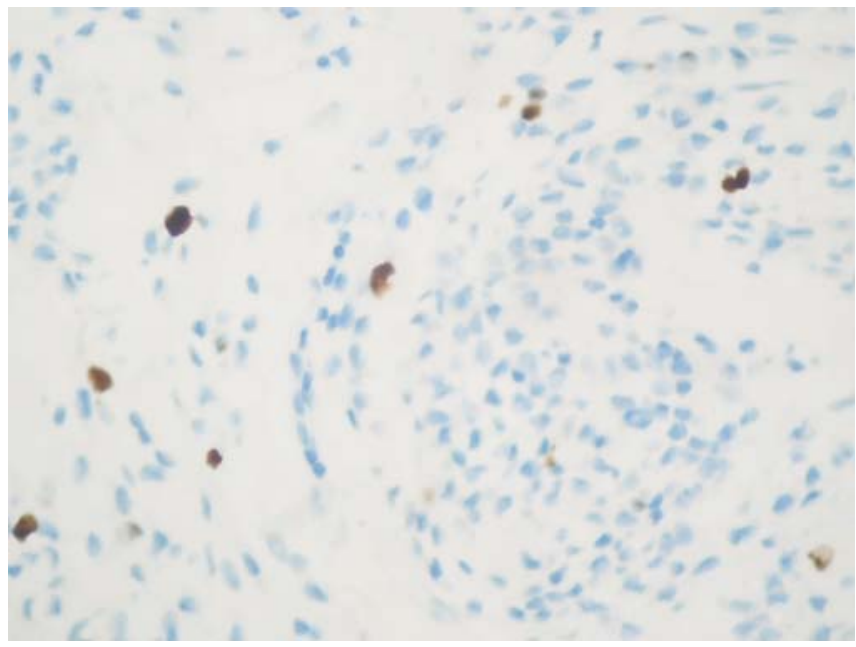

Figure 5: Ki-67 labeling is calculated as $10 \%$ with intensely nuclear staning. (Streptavidin biotinylated complement; Ki-67 [MIB1]; x400 original magnification).

Therefore differential diagnosis including tumors with associated with abundant myxoid features mimicking chordoid features including schwannoma with myxomatous change, chordoma, cartilaginous tumor, and pleomorphic adenoma of salivary gland. Schwannomas typically have reticulin stain around individual cells and are strongly positive for S-100 protein. Chordomas originate from midline structures and are composed of pathognomonic physaliphorous cells but some cells with more solid and eosinophilic cytoplasm are often present. The cells are embedded in an abundant, basophilic, metachromatic myxomatous matrix. They are strongly immunoreactive for 


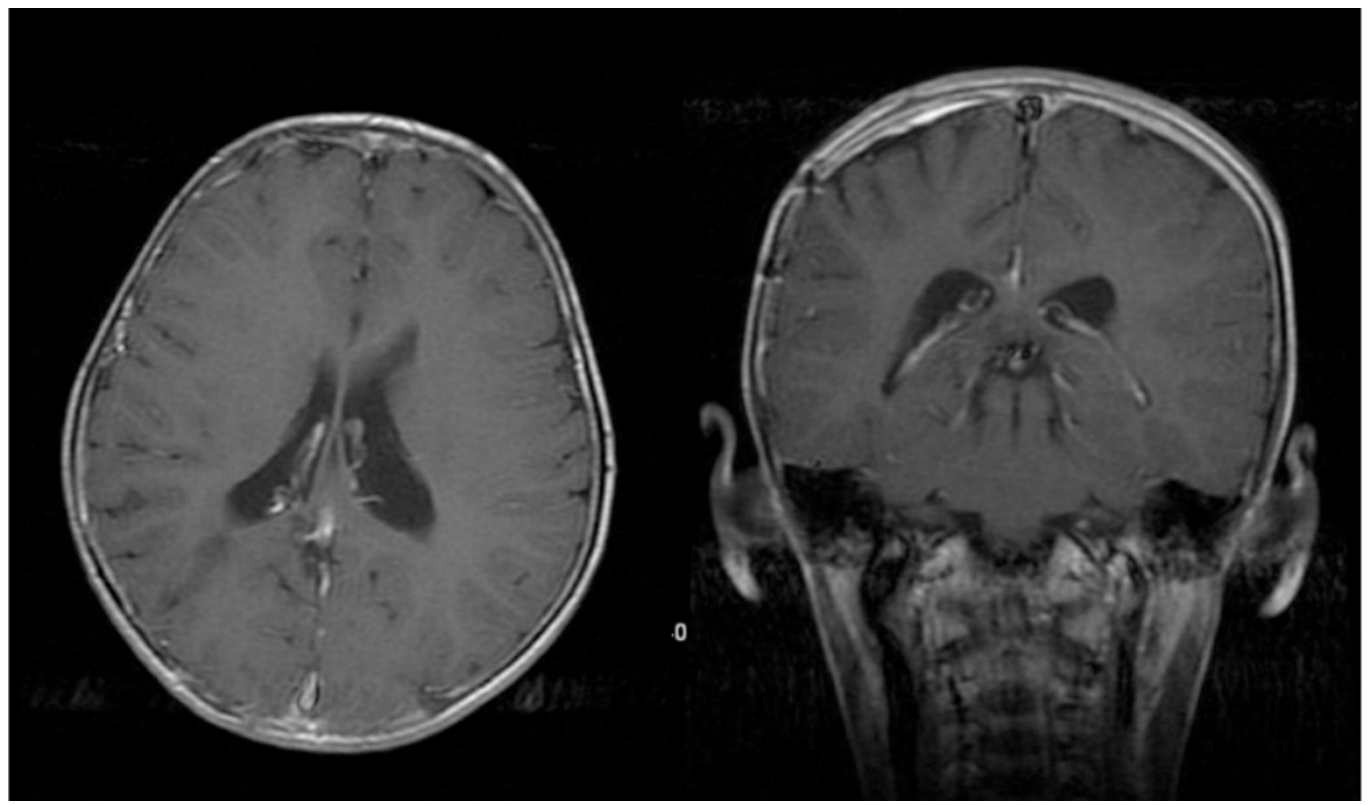

Figure 6: Postoperative MRI scan with contrast enhancement at 6 months. There is no residue of tumor and no sign of recurrence is found.

S-100 protein, cytokeratin, and also EMA. Chondrosarcomas show a mixed hyaline and myxoid type. The histologic grade is always low. Immunohistochemistry allows separation of chordoid meningioma from chondrosarcomas. Over $95 \%$ of cranial base chondrosarcoma are positive forS-100 protein but only a few of them are immunoreactive for EMA. They are negative for cytokeratin. Pleomorphic adenoma of salivary gland with abundant myxoid matrix has S-100 and EMA negativity whereas reacting with cytokeratin. By conclusion, immunohistochemical panel of tumor tissue was consistent with chordoid meningioma.

\section{FOLLOW-UP}

During the early post-op period, the patient's left hemiparesis improved, and the fever subsided. A neurological examination was performed 6 months later, and the results were considered normal. No recurrence was detected in the control cranial MRI (Figure 6). The blood test results were normal.

\section{DISCUSSION}

Hodgkin lymphoma is a malignancy of the lymphoid tissue that was defined by Sir Thomas Hodgkin in 1832 and is characterized by malignant Reed Stenberg and Hodgkin cells and characteristic cellular structures [14]. The purpose of the treatment is to cure patients with minimum complications. KT and RT alone or in combination are effective methods to treat the disease [9-12]. A large portion of the body is exposed to radiation with either $\mathrm{RT}$ alone or with $\mathrm{RT}$ in combination with KT. Many of the complications that occur during the late state of treatment are associated with radiation exposure [13, 14]. Although the disease can be controlled in over $70 \%$ of patients with the combined treatment approach [37], the risks of second primary tumors, cardiovascular disease, cerebrovascular disease and infection are increased [38-50]. Therefore, treatment with $\mathrm{KT}$ alone is preferred [51].

To consider a secondary neoplasia to be associated with therapeutic radiation, 1 - the radiation must have been delivered in the tumoral area, 2- there must be a symptomless period between the radiation therapy and onset of symptoms due to the secondary tumor, 3- the diagnosis of the tumor must be histologically verified, and 4- the new lesion must be histologically differentiated from the primary lesion $[52,53]$.

Meningiomas and gliomas are the most common tumors in later years in the patients who have received therapeutic radiation. Gliomas are generally observed in the first 5 years, and the frequency of meningiomas increases with time $[32,33]$. The first case of radiationassociated meningioma was reported by Mann et al. in 1953 [54]. The period between the radiation exposure and the development of the meningioma is approximately 9.5 years in children [55]. In the study performed by Primoz et al., the risk of secondary intracranial meningioma in the first 10 years was $0.53 \%$, with risks of $1.20 \%$ in 20 years and $8.18 \%$ in 25 years [55]. Secondary tumors of the central nervous 
Table 1: CNS Tumors After Radiotherapy for Hodgkin Lymphoma in Literature

\begin{tabular}{|c|c|c|c|c|c|c|c|}
\hline ฏ & Tumor type & $\begin{array}{l}\text { Age at } \\
\text { radiotion } \\
\text { (year) }\end{array}$ & $\begin{array}{l}\text { Radiation } \\
\text { dose }\end{array}$ & $\begin{array}{c}\text { Latency } \\
\text { period (year) }\end{array}$ & $\begin{array}{l}\text { Tumor } \\
\text { location }\end{array}$ & $\begin{array}{l}\text { Follow-up } \\
\text { period }\end{array}$ & Author (year) \\
\hline 1 & $\begin{array}{l}\text { Glioblastoma } \\
\text { multiforme }\end{array}$ & 21 & 50 & 6 & $\begin{array}{l}\text { Cervico- } \\
\text { thoracic }\end{array}$ & 10 weeks $^{a}$ & $\begin{array}{c}\text { Clifton et al. } 1980 \\
{[56]}\end{array}$ \\
\hline 2 & $\begin{array}{l}\text { Undifferentiated } \\
\text { neurogenic tumor }\end{array}$ & 3 & NS & 6 & cerebral & NS & $\begin{array}{c}\text { Schmitt et al. } 1984 \\
\text { [57] }\end{array}$ \\
\hline 3 & Gliosarcoma & 6 & NS & NS & cerebral & NS & $\begin{array}{c}\text { Takaue et al. } 1986 \\
\text { [58] }\end{array}$ \\
\hline 4 & $\begin{array}{c}\text { Astrocytoma grade } \\
\text { II-III }\end{array}$ & 19 & 40 & 7 & Cervical & 6 month & $\begin{array}{c}\text { Bazen et al. } 1990 \\
{[59]}\end{array}$ \\
\hline 5 & Meningioma & 15 & 140 & 27 & $\begin{array}{l}\text { Posterior } \\
\text { fossa }\end{array}$ & 3 year & $\begin{array}{c}\text { Deutsch et al. } 1999 \\
\text { [36] }\end{array}$ \\
\hline 6 & Meningioma & 26 & NS & 9 & Cervical & NS & $\begin{array}{c}\text { Martin et al. } 2001 \\
{[60]}\end{array}$ \\
\hline 7 & Anaplastic glioma & 30 & 40 & 9 & $\begin{array}{l}\text { Cervico- } \\
\text { thoracic }\end{array}$ & 11 month $^{\mathrm{a}}$ & $\begin{array}{l}\text { Riffaud et al. } 2006 \\
\text { [61] }\end{array}$ \\
\hline 8 & $\begin{array}{l}\text { High grade } \\
\text { astrocytoma }\end{array}$ & 23 & 180 & 3 & $\begin{array}{l}\text { Conus } \\
\text { medullaris }\end{array}$ & $\begin{array}{l}\text { Several } \\
\text { weeks }^{a}\end{array}$ & $\mathrm{Ng}$ et al. 2007 [62] \\
\hline 9 & Meningioma & 4 & 25 & 6 & $\begin{array}{l}\text { Temparo- } \\
\text { parietal }\end{array}$ & 6 month & Present case \\
\hline
\end{tabular}

${ }^{a}$ exitus date, NS: not stated.

system (CNS) in patients who received radiotherapy for Hodgkin lymphoma and have been reported in the literature are listed in Table 1.

A large number of cases of meningioma after radiotherapy for leukemia have been reported in the literature [63]. However, the development of meningioma after treatment for Hodgkin lymphoma has been reported by only Deutsch et al. in 1999 [36]. The case involved a male patient who was histologically diagnosed with a posterior fossa meningothelial meningioma 25 years after being treated with therapeutic radiotherapy at 15 years old.

In our case, the patient was diagnosed with Hodgkin lymphoma in 2006 and received radiotherapy in the same year. He had a symptomless period of approximately 6 years and then developed an intraparenchymal intracranial meningioma in the right temporoparietal region. The intracranial lesion was surgically excised. Histological evaluation revealed that it was a chordoid meningioma. In contrast to cases of meningioma reported in the literature, our patient's meningioma developed in a very short period of time after the radiation treatment. In addition, our patient's tumor was a chordoid meningioma, which is a rare histological type. According to the definition of radiation-associated tumors, secondary tumors are observed in the areas exposed to radiation $[53,54]$. In the study performed by Deutsch et al., the patient received radiotherapy in the supine position and developed a tumor in the posterior fossa due to excessive radiation exposure because the radiation beams were aimed directly at the posterior fossa, resulting in the accumulation of direct and reflected beams (Figure 4) [36].

A review by Primoz et al revealed that the development of second primary intracranial meningioma in the patients at and under 5 years old who received radiotherapy was faster than the development of such tumors in those who received radiotherapy at older ages. This period of time for development of the tumor was $16.1[55,64]$.

Many studies explaining the relationship between Hodgkin lymphoma and second primary tumors report that the risks of leukemia, breast cancer, thyroid cancer, sarcoma, and lung cancer are increased [6574]. Regarding the central nervous system, spinal cord glioma after treatment for Hodgkin lymphoma has been reported in 3 cases in the literature [56, 59, 61]. Similarly, spinal meningioma was observed in one case [60]. The approximate period of occurrence of those cases after the treatment for Hodgkin lymphoma varied between 6 and 9 years after radiotherapy $[60,61]$. The retrospective study performed by Behringer et al. with 5367 patients with Hodgkin lymphoma showed that 
lung, colorectal and breast cancers were the most common after a 72-month follow-up. The risk of developing a secondary solid tumor was $2 \%$. Of the patients who developed secondary tumors, $77.2 \%$ were treated with a combined treatment protocol [55].

Hodgkin's lymphoma is common in underdeveloped areas and low socioeconomic status. The risk of Hodgkin lymphoma makes a peak in early childhood and the $3^{\text {rd }}$ decade of life. Also risk increases with increased age [75]. Among tumors occurring during childhood, meningioma is very rare. Children accounted for only $1.9 \%$ of patients in the study of Cushing and Eisenhardt, which was performed with 313 patients with meningioma [76]. The frequency of meningioma in children was found to be approximately $2 \%$ in later studies [24]. These tumors account for 1 $4.2 \%$ of all primary intracranial tumors during childhood [17-28].

Chordoid meningiomas, which are grade 2 according to the $\mathrm{WHO}$ classification, account for only

Table 2: Reported Cases of Intraparenchymal Meningioma in Child

\begin{tabular}{|c|c|c|c|c|c|c|c|}
\hline 号 & $\begin{array}{l}\text { Age, } \\
\text { Sex }\end{array}$ & Etiology & Location & Operation & Histology & Follow up & Author (year) \\
\hline 1 & $\begin{array}{c}5 \mathrm{mos} \\
\mathrm{F}\end{array}$ & Primary & Frontal & Total & Fibroblastic & NS & $\begin{array}{l}\text { Suematsu et al. } 1974 \\
{[28]}\end{array}$ \\
\hline 2 & $0-14$ yrs, NS & Primary & NS & Craniotomy & Sarcomatous & NS & Sano et al. 1981 [79] \\
\hline 3 & $0-14$ yrs, NS & Primary & NS & Craniotomy & Fibroblastic & NS & Sano et al. 1981 [79] \\
\hline 4 & $\begin{array}{c}1 \mathrm{yrs} \\
\mathrm{M}\end{array}$ & Primary & Parietal & Total & Fibroblastic & NS & Legius et al. 1985 [35] \\
\hline 5 & $\begin{array}{c}12 \mathrm{yrs}, \\
\mathrm{M}\end{array}$ & Primary & Temporal & Partial & Transitional & 3 yrs & Drake et al. 1986 [19] \\
\hline 6 & $\begin{array}{l}7 \mathrm{yrs} \\
\mathrm{M}\end{array}$ & Primary & Frontal & Total & Fibroblastic & NS & $\begin{array}{c}\text { Schroeder et al. } 1987 \\
{[80]}\end{array}$ \\
\hline 7 & 11 mos, M & Primary & Frontal & Total & Fibroblastic & $5 \mathrm{yrs}$ & Kimura et al. 1987 [81] \\
\hline 8 & $\begin{array}{c}2 \mathrm{yrs} \\
\mathrm{F}\end{array}$ & Primary & Frontal & Total & Psammo-matous & $4 \mathrm{mos}$ & $\begin{array}{c}\text { Mamourian et al. } 1991 \\
{[82]}\end{array}$ \\
\hline 9 & $\begin{array}{c}6 \text { yas, } \\
\mathrm{F}\end{array}$ & Primary & Frontal & Total & Transitional & 2 yrs & $\begin{array}{c}\text { Matsumoto et al. } 1992 \\
\text { [83] }\end{array}$ \\
\hline 10 & $\begin{array}{c}12 \text { yrs, } \\
F\end{array}$ & Primary & Temporal & Total & Meningo-thelial & NS & Kaneko et al. 1993 [84] \\
\hline 11 & $\begin{array}{c}2 y r s, \\
M\end{array}$ & Primary & Temporal & Craniotomy & Fibroblastic & NS & Miwa et al. 1996 [85] \\
\hline 12 & $\begin{array}{l}1 \mathrm{yrs} \\
\mathrm{F}\end{array}$ & Primary & Frontal & Total & Fibroblastic & $2 \mathrm{yrs}$ & Kohama et al. 1996 [34] \\
\hline 13 & $\begin{array}{c}2 \mathrm{yrs} \\
\mathrm{F}\end{array}$ & Primary & Brain stem & Partial & Clear cell & NS & Teo et al. 1998 [86] \\
\hline 14 & $\begin{array}{c}14 \mathrm{yrs}, \\
\mathrm{M}\end{array}$ & Primary & Temporal & Total & Fibroblastic & 3 yrs & $\begin{array}{c}\text { Karadereler et al. } 2004 \\
\text { [87] }\end{array}$ \\
\hline 15 & $\begin{array}{c}16 \mathrm{yrs} \\
\mathrm{M}\end{array}$ & Primary & Occipital & Total & Atypical & $\begin{array}{l}1 \mathrm{yrs} \\
6 \mathrm{mos}\end{array}$ & Zhang et al. 2007 [88] \\
\hline 16 & $\begin{array}{c}10 \mathrm{yrs}, \\
\mathrm{M}\end{array}$ & Primary & Frontal & Total & Meningo-thelial & $5 \mathrm{mos}$ & Shimbo et al. 2011 [77] \\
\hline 17 & $\begin{array}{c}10 \mathrm{yrs}, \\
\mathrm{M}\end{array}$ & Secondary & $\begin{array}{l}\text { Temparo- } \\
\text { parietal }\end{array}$ & Total & Chordoid & $6 \mathrm{mos}$ & Present case \\
\hline
\end{tabular}

F: female, M: male, Mos: months, Yrs: years, NS: not stated, Partial: partial removal, Total: total removal, Primary: primary tumor of brain, Secondary: secondary to another tumor. 
$0.5-1 \%$ of all meningiomas [30]. As with all meningiomas, the chordoid form is common in adults and very rare in children [26, 64].

In a review of the literature describing meningiomas during childhood that were histopathologically examined, the frequency of grade 2 meningioma varied between $2 \%$ and $5 \%$. In a series of 38 patients, grade 2 meningioma accounted for $21.9 \%$, and only $4.9 \%$ (2 of 38 patients) had chordoid meningioma pathology [24]. During childhood, convexity and parasagittal meningiomas are the most common, followed by meningiomas at the skull base and the posterior fossa [24]. Intraparenchymal or subcortical meningiomas without dural connections are even rarer [29]. There are only 24 cases of intraparenchymal meningioma reported in the literature [77]. Of these, only one was a chordoid meningioma [78]. The cases of intraparenchymal meningiomas during childhood that have been published in the literature are presented in Table 2.
The term 'chordoid meningeal tumor' was used by Kepes et al. for the first time in 1988 [89]. Chordoid meningioma is a rare variant of meningioma and accounts for $0.5-2 \%$ of all meningiomas [30, 31, 90, 91]. Chordoid meningioma has a great risk of recurrence and aggressive growth [92-94] and is classified as grade 2 according to WHO [92]. To date, 53 cases have been published in the literature, and only 6 of these patients were children [26, 31, 95, 96]. Of these 53 tumors, 4 tumors were located in the infratentorial region and 11 in the supratentorial region. A large proportion of supratentorially located tumor are localized around the falx cerebri in the convexity [95]. Intraparenchymal chordoid meningioma has not been published in the literature.

In our case, the secondary meningioma was located in the parenchyma without dural connections. The presented case is the second case of intraparenchymal chordoid meningioma in the literature and is the only case in a child.

Table 3: Radiation Induced Meningioma with Short Latency Period

\begin{tabular}{|c|c|c|c|c|c|c|c|c|}
\hline \multirow[b]{2}{*}{ 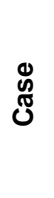 } & \multicolumn{4}{|c|}{ Primary Malignancy } & \multicolumn{3}{|c|}{ Radiation induced meningioma } & \multirow[b]{2}{*}{ Author (year) } \\
\hline & $\begin{array}{l}\text { Age, } \\
\text { Sex }\end{array}$ & Histology & $\begin{array}{c}\text { Cranial } \\
\text { radiation } \\
\text { TD/fr (cGy) }\end{array}$ & $\begin{array}{l}\text { Latency } \\
\text { Period } \\
\text { (months) }\end{array}$ & Location & Histology & Follow up & \\
\hline 1 & $4, \mathrm{~F}$ & $\begin{array}{l}\text { Optic nerve } \\
\text { glioma }\end{array}$ & 65 & 48 & Basifrontal & $\begin{array}{c}\text { Anaplastic } \\
\text { meningioma }\end{array}$ & 1 year & $\begin{array}{c}\text { Mann et al. } \\
1953 \text { [54] }\end{array}$ \\
\hline 2 & $4, M$ & $\begin{array}{l}\text { Medullo- } \\
\text { blastoma }\end{array}$ & 46 & 60 & Right frontal & NS & NS & $\begin{array}{c}\text { Moss et al. } \\
1988 \text { [98] }\end{array}$ \\
\hline 3 & $2,1 \mathrm{M}$ & $\begin{array}{l}\text { Left pontine } \\
\text { glioma }\end{array}$ & 55 & 42 & Left Temporal & $\begin{array}{c}\text { Benign } \\
\text { meningioma }\end{array}$ & NS & $\begin{array}{c}\text { Rusyniak et al. } \\
1992 \text { [99] }\end{array}$ \\
\hline 4 & $? ?$ & $\begin{array}{l}\text { Recurrent } \\
\text { Pituitary } \\
\text { Adenoma }\end{array}$ & HD & 12 & Skull base & NS & NS & $\begin{array}{c}\text { Bliss et al. } 1994 \\
{[100]}\end{array}$ \\
\hline 5 & $7, \mathrm{M}$ & $\begin{array}{c}\text { Cranio- } \\
\text { pharyngioma }\end{array}$ & 50 & 24 & Right temporal & $\begin{array}{c}\text { Atypical } \\
\text { meningioma }\end{array}$ & 2 years & $\begin{array}{c}\text { Kano et al. } 1994 \\
{[101]}\end{array}$ \\
\hline 6 & $2, F$ & $\begin{array}{l}\text { Medullo- } \\
\text { blastoma }\end{array}$ & 48.25 & 60 & $\begin{array}{l}\text { Convexity } \\
\text { meningioma }\end{array}$ & $\begin{array}{c}\text { Atypical } \\
\text { meningioma }\end{array}$ & NS & $\begin{array}{c}\text { Mack and } \\
\text { Wilson } 1993 \\
{[102]}\end{array}$ \\
\hline 7 & $4.5, \mathrm{M}$ & $\begin{array}{l}\text { Medullo- } \\
\text { blastoma }\end{array}$ & $\mathrm{HD}$ & 26 & Parasaggital & NS & NS & $\begin{array}{c}\text { Starshak } 1996 \\
{[103]}\end{array}$ \\
\hline 8 & $9, \mathrm{~F}$ & Pineo-blastoma & $\mathrm{HD}$ & 42 & Parasaggital & NS & NS & $\begin{array}{c}\text { Starshak } 1996 \\
{[103]}\end{array}$ \\
\hline 9 & $<3$, ? & $\begin{array}{l}\text { Medullo- } \\
\text { blastoma }\end{array}$ & 53.2 & 35 & NS & NS & NS & $\begin{array}{c}\text { Duffner et al. } \\
1998 \text { [104] }\end{array}$ \\
\hline 10 & $9, M$ & $\begin{array}{l}\text { Cutaneos } \\
\text { angioma }\end{array}$ & 25 & 60 & Parietooccipital & Meningothelial & NS & $\begin{array}{c}\text { Caroli et al } 2005 \\
{[105]}\end{array}$ \\
\hline 11 & $11, M$ & $\begin{array}{l}\text { Medullo- } \\
\text { blastoma }\end{array}$ & 54 & 14 & $\begin{array}{l}\text { Multiple skull } \\
\text { base }\end{array}$ & $\begin{array}{c}\text { Atypical } \\
\text { meningioma }\end{array}$ & NS & $\begin{array}{l}\text { Choudhary et } \\
\text { al. } 2006 \text { [106] }\end{array}$ \\
\hline 12 & $4, M$ & $\begin{array}{l}\text { Hodgkin } \\
\text { lymphoma }\end{array}$ & 25 & 60 & $\begin{array}{l}\text { Temparo- } \\
\text { parietal }\end{array}$ & Chordoid & 6 month & Present case \\
\hline
\end{tabular}

F: female, M: male, HD: high dose, NS: not stated. 
Radiation is a clear cause of meningioma. Meningiomas are the most common radiationassociated tumors of the central nervous system. Particularly in children, radiation exposure in high doses increases the risk of radiation-associated tumor development by 10 -fold $[97,98]$. The cases of radiation-associated meningioma during childhood after a short latent period in the early stage in the literature are listed in Table $\mathbf{3}$.

Radiation-associated meningiomas typically occur in the early ages. These tumors may primarily arise from the areas exposed to radiation and may be multifocal. The latent period is shorter in children than in adults [97]. In a study performed by Primoz et al., 170000 patients were retrospectively evaluated, and of these, 1227 were at or under 16 years old. Only 5 patients were diagnosed with meningiomas that met the criteria of radiation-associated tumors [55]. The ages of those patients varied from 3 to 13 , and the patients received radiotherapy for different reasons. The first meningioma developed 9.5 years after radiotherapy and the average time is 19.7 years [55]. The risk of developing secondary intracranial meningioma was investigated in the same study and was found to be $0.53 \%$ for the first 10 years, $1.2 \%$ for 20 years and $8.18 \%$ for 25 years after radiotherapy [55]. The children who did not receive radiotherapy did not develop meningioma. Multiple meningiomas were found in the $60 \%$ of the patients who were diagnosed with meningioma [107], and only $20 \%$ of them [108] exhibited atypical meningioma pathology [55]. In the same study, there were 126 cases of radiationassociated meningioma, and of these, 68\% involved radiotherapy during childhood. The latent period was shorter in children, although there was no significant relationship between the age of radiotherapy and the latent period; the average latent period is 16.1 years [55].

In the case presented herein, the patient, who received radiotherapy after a diagnosis of Hodgkin lymphoma, developed meningioma in a very short period of time, in contrast to other cases reported in the literature. After a rare pathology, this tumor developed into a very rare histopathological type in an unusual location, thus representing a rare complication. The radiotherapy-associated intraparenchymal chordoid meningioma was totally excised. The patient was stable in terms of his reaction to combined radiotherapy and chemotherapy and to the status of his Hodgkin lymphoma, and his intracranial pathology was immunohistochemically examined. Immunohisto- chemical examinations are used primarily to define meningiomas. MIB-1 labeling, which is considered to be closely related to the histological grading of meningiomas, is a technique that can be used to visualize proliferative activity [109-111]. The MIB-1 index is a good tool to evaluate the risk of malignancy and recurrence [112-114]. There are studies in the literature showing that the MIB-1 index has higher values in atypical and malignant meningiomas than in typical meningiomas $[113,115,118]$. It is stated in the literature that a higher MIB-1 index is closely related with recurrence $[113,115,117-119]$. The MIB-1 index was $10 \%$ in our case. This level indicates a high risk of recurrence, and therefore, this patient must be monitored closely.

The negative prognostic factors in meningioma are as follows: a) atypical or anaplastic histological stage, b) aggressive histological variant (clear cell, chordoid, papillary, rhabdoid), c) young patient ( $<40$ years), d) high MIB-1 index, e) affected anterior visual path, and f) genetic changes related to progression [95]. The MIB-1 index is approximately 3.8 in benign meningiomas, 7.2 in atypical meningiomas and 14.7 in anaplastic meningiomas [95]. In a study performed by Couce et al., after a long-term follow-up, one or more recurrences were observed in $39 \%$ of patients with meningiomas, with the recurrences occurring 5.6 years later on average [120]. All of the patients underwent subtotal resection except for one patient with recurrence. A total of $87.7 \%$ of relapsed patients had over $50 \%$ chordoid patterns [120].

Our patient is included in the high risk group for recurrence due to the histological stage, the chordoid tumor type, his age, the tumor's high MIB-1 index. The total excision of intracranial lesion reduces the risk of recurrence.

\section{CONCLUSION}

Although Hodgkin lymphoma is a disease that can be treated with radiotherapy and/or chemotherapy in every stage, the therapy-associated secondary tumors that can occur in the late stage are the primary cause of mortality and morbidity for patients with Hodgkin lymphoma. Surgeons must remember that radiationassociated meningiomas may occur in the early stage of the treatment as well as in the late stage. Young patients with grade 2 chordoid meningiomas should be followed up in case of recurrence, and those with higher Ki-67 values are highly expected to relapse. 


\section{REFERENCES}

[1] Rosen PJ, Lavey RS, Haskell CM: Hodgkin's Disease; in Haskell CM (ed): Cancer treatment, 4th ed. Philadelphia, W.B. Saunder Company, 1995; pp. 951-979.

[2] DeVita VT, Mauch PM, Harris NL. Hodgkin's Disease; in DeVita VT, Hellman S, Rosenberg SA (eds): Cancer Principles and Practice of Oncology, 5th ed. Philadelphia, Lippincoltt-Raven, 1997; pp. 2242-2283.

[3] Stein RS. Hodgkin's Disease; in Lee RG, Foerster J, Lukens $\mathrm{J}$ et al. (eds). Wintrobe's Clinical Hematology. 10th ed. Egypt, Mass Pub, 1999; pp. 2538-2571.

[4] Horning JH. Hodgkin Lymphoma; in Beutler E, Lichtman MA, Coller BS, Kipps TJ, Seligsohn U (eds), Williams Hematology, 6th ed. McGraw-hill, 2001; pp. 1215-1235.

[5] Bernhards J, Fischer R, Hubner K, Schwarze EW, Georgii A. Histopatological classification of Hodgkin's lymphoma. Results from the reference pathology of the German Hodgkin's trial. Annals of Oncology 1992; 3(4): 31-33. http://dx.doi.org/10.1093/annonc/3.suppl 4.S31

[6] Thomas RK, Re D, Zander T, Wolf J, Diehl V. Epidemiology and etiology of Hodgkin's lymphoma. ESMO 2002; 147-152.

[7] Jaffe ES, Harris NL, Stein H, Vardiman JW, eds. World Health Organization Classification of Tumours: Pathology and Genetics of Tumours of Haematopoietic and Lymphoid Tissues. Lyon, France: IARC Press; 2001.).

[8] Altuntas F, Eser B, Kaplan B, Canoz O, Gundogan K, Ozkan $\mathrm{M}$, et al. Hodgkin hastalarında ilk basamak tedavi sonucları: tek merkez deneyimi. THOD 2003; 2(13): 79-86.

[9] Ekstrand BC, Lucas JB, Horwitz SM, Fan Z, Breslin S, Hoppe $\mathrm{RT}$, et al. Rituximab in lymphocyte predominant Hodgkin's disease: results of a Phase II Trial. Blood 2003; 101: 42854289.

http://dx.doi.org/10.1182/blood-2002-08-2644

[10] Rehwald U, Schulz H, Reiser M, Sieber M, Staak JO, Morschhauser F, et al. Treatment of relapsed CD20+ Hodgkin lymphoma with the monoclonal antibody rituximab is effective and well tolerated: results of a phase 2 trial of the German Hodgkin Lymphoma Study Group. Blood 2003; 101(2): 420-424.

http://dx.doi.org/10.1182/blood.V101.2.420

[11] Diehl V, Franklin J, Hasenclever D, Tesch H, Pfreundschuh $\mathrm{M}$, Lathan $\mathrm{B}$, et al. BEACOPP, a new dose escalated and accelerated regimen, is at least as effective as COPP/ABVD in patients with advanced stage Hodgkin's lymphoma: interim report from a trial of the German Hodgkin's Lymphoma Study Group. Ann Oncol 1997; 8: 143. http://dx.doi.org/10.1023/A:1008294312741

[12] Nissen N, Nordentoft A. Radiotherapy versus combined modality treatment of stage I and II Hodgkin's disease. Cancer Tret Rep 1982; 66: 799-803.

[13] Dores GM, Metayer C, Curtis RE, Lynch CF, Clarke EA, Glimelius B, et al. Second malignant neoplasmsamong longtermsurvivors ofHodgkin's disease: a population-based evaluation over 25 years. J Clin Oncol 2002; 20: 3484-94. http://dx.doi.org/10.1200/JCO.2002.09.038

[14] Green DM, Hyland A, Barcos MP, Reynolds JA, Lee RJ, Hall $\mathrm{BC}$, et al. Second malignant neoplasmsafter treatment forHodgkin's disease in childhood or adolescence. J Clin Oncol 2000; 18: 1492-9.

[15] Aleman BM, van den Belt-Dusebout AW, Klokman WJ, Van't VeerMB, BartelinkH, vanLeeuwenFE. Long-termcausespecific mortality of patients treated for Hodgkin's disease. $\mathrm{J}$ Clin Oncol 2003; 21: 3431-9. http://dx.doi.org/10.1200/JCO.2003.07.131

[16] Oeffinger KC, Mertens AC, Sklar CA, Kawashima T, Hudson MM, Meadows AT, et al. Childhood Cancer Survivor. Chronic health conditions in adult survivors of childhood cancer. $\mathrm{N}$ Engl J Med 2006; 355: 1572-82.

http://dx.doi.org/10.1056/NEJMsa060185
[17] Amirjamshidi A, Mehrazin M, Abbassioun K. Meningiomas of the central nervous system occurring below the age of 17 : report of 24 cases not associated with neurofibromatosis and review of literature. Childs Nerv Syst 2000; 16: 406-416. http://dx.doi.org/10.1007/s003819900205

[18] Deen HG Jr, Scheithauer BW, Ebersold MJ. Clinical and pathological study of meningiomas of the first two decades of life. J Neurosurg 1982; 56: 317-322. http://dx.doi.org/10.3171/ins.1982.56.3.0317

[19] Drake JM, Hendrick EB, Becker LE, Chuang SH, Hoffman HJ, Humphreys RP. Intracranial meningiomas in children. Pediatr Neurosci 1985-1986; 12: 134-139. http://dx.doi.org/10.1159/000120235

[20] Emoto S, Okada H, Hayami T. Subcortical meningioma: Report of a case of successful removal. Nihon Geka Hokan 1954; 23: 397-400.

[21] Ferrante L, Acqui M, Artico M, Mastronardi L, Rocchi G, Fortuna A. Cerebral meningiomas in children. Childs Nerv Syst 1989; 5: 83-86.

http://dx.doi.org/10.1007/BF00571115

[22] Germano IM, Edwards MS, Davis RL, Schiffer D. Intracranial meningiomas of the first two decades of life. J Neurosurg 1994; 80: 447-453.

http://dx.doi.org/10.3171/jns.1994.80.3.0447

[23] Herz DA, Shapiro K, Shulman K. Intracranial meningiomas in infancy, childhood and adolescence. Review of the literature and addition of 9 case reports. Childs Brain 1980; 7: 43-56.

[24] Menon G, Nair S, Sudhir J, Rao BR, Mathew A, Bahuleyan B. Childhood and adolescent meningiomas: a report of 38 cases and review of literature. Acta Neurochir (Wien) 2009; 151: $239-244$

http://dx.doi.org/10.1007/s00701-009-0206-8

[25] Rochat $P$, Johannesen $\mathrm{HH}$, Gjerris F. Long-term follow up of children with meningiomas in Denmark: 1935 to 1984. J Neurosurg 100(2 Suppl Pediatrics) 2004; 179-182.

[26] Rushing EJ, Olsen C, Mena H, Rueda ME, Lee YS, Keating $\mathrm{RF}$, et al. Central nervous system meningiomas in the first two decades of life: a clinicopathological analysis of 87 patients. J Neurosurg 2005; 103(6 Suppl): 489-495.

[27] Sandberg DI, Edgar MA, Resch L, Rutka JT, Becker LE, Souweidane MM. MIB-1 staining index of pediatric meningiomas. Neurosurgery 2001; 48: 590-597. http://dx.doi.org/10.1097/00006123-200103000-00027

[28] Suematsu K, Tokuda S, Miyazaki Y. Intracranial Meningioma in a five-month-old infant: A case report and review of the literature. No To Shinkei 1974; 26: 453-464 (Japanese).

[29] Cushing H, Eisenhardt L. Meningiomas Without Dural Attachment. Springfield, Illinois, Charles C Thomas, 1938; pp. 133-168.

[30] Couce ME, Aker FV, Scheithauer BW. Chordoid meningioma: A clinicopathologic study of 42 cases. Am J Surg Pathol 2000; 24: 899-905.

http://dx.doi.org/10.1097/00000478-200007000-00001

[31] Mullassery D, O'Brien DF, Williams D, Crooks D, Mallucci C, Pizer $\mathrm{B}$, et al. Malignant disseminated chordoid meningioma in a 12-year-old child: a role for early cranial and spinal radiation treatment after subtotal resection. Child's Nerv Syst 2006; 22: 1344-1350. http://dx.doi.org/10.1007/s00381-006-0096-5

[32] Walter AW, Hancock ML, Pui CH, Hudson MM, Ochs JS, Rivera GK, et al. Secondary brain tumors in children treated for acute lymphoblastic leukemia at St Jude Children's Research Hospital. J Clin Oncol 1998; 16: 3761-3767.

[33] Neglia JP, Robison LL, Stovall M, Liu Y, Packer RJ, Hammond $S$, et al. New primary neoplasms of the central nervous system in survivors of childhood cancer: a report from the Childhood Cancer Survivor Study. J Natl Cancer Inst. 2006; 98: 1528-1537.

http://dx.doi.org/10.1093/jnci/djj411 
[34] Kohama I, Sohma T, Nunomura K, Igarashi K, Ishikawa A. Intraparenchymal meningioma in an infant-case report. Neurol Med Chir (Tokyo) 1996; 36: 598-601. http://dx.doi.org/10.2176/nmc.36.598

[35] Legius E, Vles JS, Casaer P, Plets C, Dom R. Intraparenchymal meningioma in a 14-month-old infant: case report. Brain Dev 1985; 7: 622-624.

http://dx.doi.org/10.1016/S0387-7604(85)80011-5

[36] Deutsch M, Rosenstein M, Figura JH. Meningioma after radiotherapy for Hodgkin's disease. Am J Clin Oncol 1999; 22(4): 361-3.

http://dx.doi.org/10.1097/00000421-199908000-00007

[37] Engert A, Diehl V, Franklin J, hri A, Dörken B, Ludwig WD, et al. Escalateddose BEACOPP in the treatment of patients with advanced-stage Hodgkin's lymphoma: 10 years of follow-up of the GHSG HD9 study. J Clin Oncol 2009; 27(27): 4548-4554 http://dx.doi.org/10.1200/JCO.2008.19.8820

[38] Björkholm M, Holm G, Mellstedt H. Immunocompetence in patients with Hodgkin's disease; in Lacher M, Redman J, (eds): Consequences of Survival in Hodgkin's Disease. New York, NY, Lea \&Febiger, 1990; pp. 112-150.

[39] van Leeuwen FE, Chorus AM, van den Belt-Dusebout AW, Hagenbeek A, Noyon R, van Kerkhoff EH, et al. Leukemia risk following Hodgkin's disease: relation to cumulative dose of alkylating agents, treatment with teniposide combinations, number of episodes of chemotherapy, and bone marrow damage. J Clin Oncol 1994; 12(5): 1063-1073.

[40] Hoppe RT. Hodgkin's disease: complications of therapy and excess mortality. Ann Oncol. 1997; 8 Suppl 1: 115-118. http://dx.doi.org/10.1093/annonc/8.suppl 1.S115

[41] Salloum E, Jillella AP, Nadkarni R, Seropian S, Hu GL, D'Andrea $\mathrm{E}$, et al. Assessment of pulmonary and cardiac function after high dose chemotherapy with BEAM and peripheral blood progenitor cell transplantation. Cancer. 1998; 82(8): 1506-1512. http://dx.doi.org/10.1002/(SICl)10970142(19980415)82:8<1506::AID-CNCR12>3.0.CO;2-8

[42] van Leeuwen F, Swerdlow A, Valagussa $P$, et al. Second cancers after treatment of Hodgkin's disease; in Mauch PM, Armitage JO, Diehl V, et al, eds: Hodgkin's Disease. Philadelphia, PA, Lippincott Williams \& Wilkins, 1999; pp. 607-632.

[43] Swerdlow AJ, Barber JA, Hudson GV, Cunningham D, Gupta RK, Hancock BW, et al. Risk of second malignancy after Hodgkin's disease in a collaborative British cohort: the relation to age at treatment. J Clin Oncol 2000; 18(3): 498509.

[44] Ng AK, Bernardo MP, Weller E, Backstrand KH, Silver B, Marcus KC, et al. Long-term survival and competing causes of death in patients with early-stage Hodgkin's disease treated at age 50 or younger. J Clin Oncol 2002; 20(8): 21012108.

http://dx.doi.org/10.1200/JCO.2002.08.021

[45] Adams MJ, Lipsitz SR, Colan SD, Tarbell NJ, Treves ST, Diller $\mathrm{L}$, et al. Cardiovascular status in long-term survivors of Hodgkin's disease treated with chest radiotherapy. J Clin Oncol 2004; 22(15): 3139-3148.

http://dx.doi.org/10.1200/JCO.2004.09.109

[46] Landgren $O$, Björkholm $M$, Konradsen $H$, Söderqvist $M$, Nilsson B, Gustavsson A, et al. A prospective study on antibody response to repeated vaccinations with pneumococcal capsular polysaccharide in splenectomized individuals with special reference to Hodgkin's lymphoma. J Internal Med 2004; 255(6): 664-673.

http://dx.doi.org/10.1111/j.1365-2796.2004.01312.x

[47] Chow LM, Nathan PC, Hodgson DC, Jenkin D, Weitzman S, Grant RM, et al. Survival and late effects in children with Hodgkin's lymphoma treated with MOPP/ABV and lowdose, extended-field irradiation. J Clin Oncol 2006; 24(36): 57355741.

http://dx.doi.org/10.1200/JCO.2006.05.6879

[48] Swerdlow AJ, Higgins CD, Smith P, Cunningham D, Hancock BW, Horwich A, et al. Myocardial infarction mortality risk after treatment for Hodgkin disease: a collaborative British cohort study. J Natl Cancer Inst 2007; 99(3): 206-214.

http://dx.doi.org/10.1093/jnci/djk029

[49] Heidenreich PA, Schnittger I, Strauss HW, Vagelos RH, Lee $\mathrm{BK}$, Mariscal CS, et al. Screening for coronary artery disease after mediastinal irradiation for Hodgkin's disease. J Clin Oncol 2007; 25(1): 43-49. http://dx.doi.org/10.1200/JCO.2006.07.0805

[50] De Bruin ML, Dorresteijn LDA, van't Veer MB, Krol AD, van der Pal HJ, Kappelle AC, et al. Increased risk of stroke and transient ischemic attack in 5-year survivors of Hodgkin lymphoma. J Natl Cancer Inst 2009; 101(13): 928-937. http://dx.doi.org/10.1093/jnci/djp147

[51] Straus DJ. Chemotherapy only for localized Hodgkin lymphoma. J Intern Med 2011: 270(3): 197-205. http://dx.doi.org/10.1111/j.1365-2796.2011.02410.x

[52] Cahan WG, Woodard HQ, Higinbotham NL, Stewart FW, Coley BL. Sarcoma arising in irradiated bone: report of eleven cases. Cancer 1948; 1: 3-29.

http://dx.doi.org/10.1002/1097-0142(194805)1:1<3::AIDCNCR2820010103>3.0.CO;2-7

[53] Liwnicz BH, Berger TS, Liwnicz RG, Aron BS. Radiationassociated gliomas: a report of four cases and analysis of postradiation tumors. Neurosurgery 1985; 17(3): 436-45. http://dx.doi.org/10.1227/00006123-198509000-00007

[54] Mann I, Yates PC, Ainslie JP. Unusual case of double primary orbital tumor. Br J Ophthalmol 1953; 37: 758-762. http://dx.doi.org/10.1136/bjo.37.12.758

[55] Behringer K, Josting A, Schiller $P$, Eich HT, Bredenfeld $H$, Diehl V, et al. German Hodgkin Lymphoma Study Group. Solid tumors in patients treated for Hodgkin's disease: a report from the German Hodgkin Lymphoma Study Group. Ann Oncol 2004 Jul; 15(7): 1079-85.

http://dx.doi.org/10.1093/annonc/mdh273

[56] Clifton MD, Amromin GD, Perry MC, Abadir R, Watts C, Levy N. Spinal cord glioma following irradiation for Hodgkin's disease. Cancer 1980; 45: 2051-2005.

http://dx.doi.org/10.1002/1097-

0142(19800415)45:8<2051::AID

CNCR2820450811>3.0.CO;2-3

[57] Schmitt K, Tulzer W. Second tumor following Hodgkin's disease. Padiatr Padol 1984; 19(3): 259-62.

[58] Takaue Y, Sullivan MP, Ramirez I, Cleary KR, van Eys J. Second malignant neoplasm in treated Hodgkin's disease. Report of a patient and scope of the problem. Am J Dis Child 1986; 140(1): 49-51. http://dx.doi.org/10.1001/archpedi.1986.02140150051032

[59] Bazan C, New PZ, Kagan-Hallet KS. MRI of radiation induced spinal cord glioma. Neuroradiology 1990; 32: 331333.

http://dx.doi.org/10.1007/BF00593057

[60] Martin AJ, Hammond CJ, Dobbs HJ, Al-Sarraj S, Thomas NW. Spinal meningioma after treatment for Hodgkin disease. Case report. J Neurosurg 2001; 95(2 Suppl): 232-5.

[61] Riffaud L, Bernard M, Lesimple T, Morandi X. Radiationinduced spinal cord glioma subsequent to treatment of Hodgkin's disease: case report and review. Journal of NeuroOncology 2006; 76: 207-211. http://dx.doi.org/10.1007/s11060-005-5532-y

[62] Ng C, Fairhall J, Rathmalgoda C, Stening W, Smee R. Spinal cord glioblastoma multiforme induced by radiation after treatment for Hodgkin disease. Case report. J Neurosurg Spine 2007; 6(4): 364-7. http://dx.doi.org/10.3171/spi.2007.6.4.14 
[63] Banerjee J, Pääkkö E, Harila $M$, Herva R, Tuominen J, Koivula $A$, et al. Radiation-induced meningiomas: a shadow in the success story of childhood leukemia. Neuro Oncol 2009; 11(5): 543-9.

http://dx.doi.org/10.1215/15228517-2008-122

[64] Strojan P, Popovic M, Jereb B. Secondary intracranial meningiomas after high-dose cranial irradiation: report of five cases and review of the literature. Int $\mathrm{J}$ Radiat Oncol Biol Phys 2000; 48: 65-73.

http://dx.doi.org/10.1016/S0360-3016(00)00609-X

[65] lacono RP, Apuzzo MLJ, Davis RL, Tsai FY. Multiple meningiomas following radiation therapy for medulloblastoma. J Neurosurg 1981; 55: 282-6. http://dx.doi.org/10.3171/jns.1981.55.2.0282

[66] Deutsch M. Meningioma; in Deutsch M, ed: Management of childhood brain tumors. Boston, Kluwer Academic Publishers, 1990; pp. 357-68. http://dx.doi.org/10.1007/978-1-4613-1501-8 14

[67] Hawkins MM, Draper GJ, Kingston JE. Incidence of second primary tumours among childhood cancer survivors. $\mathrm{Br} \mathrm{J}$ Cancer 1987; 56: 339-47.

http://dx.doi.org/10.1038/bjc.1987.200

[68] Bhatia S, Robison LL, Oberlin O, Greenberg M, Bunin G, Fossati-Bellani $F$, et al. Breast cancer and other second neoplasms after childhood Hodgkin's disease. N Eng J Med 1996; 334: 745-50.

http://dx.doi.org/10.1056/NEJM199603213341201

[69] Meadows AT, Baum E, Fossati-Bellani F, Green D, Jenkin $\mathrm{RD}$, Marsden $\mathrm{B}$, et al. Second malignant neoplasms in children: an update from the late effects study group. J Clin Oncol 1985; 3: 532-8.

[70] Wolden SL, Lamborn KR, Cleary SF, Tate DJ, Donaldson SS. Second cancers following pediatric Hodgkin's disease. J Clin Oncol 1998; 16: 536-44.

[71] Baccarani M, Bosi A, Papa G. Second malignancy in patients treated for Hodgkin's disease. Cancer 1980; 46: 1735-40. http://dx.doi.org/10.1002/10970142(19801015)46:8<1735::AIDCNCR2820460806>3.0.CO;2-3

[72] Swerdlow AJ, Douglas AJ, Vaughan Hudson G, Vaughan Hudson B, MacLennan KA. Risk of second primary cancer after Hodgkin's disease in patients in the British National Lymphoma Investigation: relationships to host factors, histology and stage of Hodgkin's disease, and splenectomy. Br J Cancer 1993; 68: 1006-11. http://dx.doi.org/10.1038/bjc.1993.470

[73] Prior P, Pope DJ. Hodgkin's disease: subsequent primary cancers in relation to treatment. $\mathrm{Br} \mathrm{J}$ Cancer 1988; 58: 512-7. http://dx.doi.org/10.1038/bjc.1988.253

[74] Kushner BH, Zauber A, Tan CTC. Second malignancies after childhood Hodgkin's disease. Cancer 1988; 62: 1364-70.

http://dx.doi.org/10.1002/1097$0142(19881001) 62: 7<1364::$ AlD CNCR2820620721>3.0.CO;2-T

[75] Lin HM, Teitell MA. Second malignancy after treatment of pediatric Hodgkin disease. J Pediatr Hematol Oncol 2005; 27(1): 28-36.

http://dx.doi.org/10.1097/01.mph.0000150740.80690.d4

[76] Cushing $\mathrm{H}$, Eisenhardt L. Serial enumeration of meningiomas; in Thomas CC (ed): Meningiomas. their classification, regional behaviour, life history, and surgical end results. Thomas, Springfield, 1938; pp. 534-570.

[77] Shimbo D, Kato T, Takeda M, Ikeda H. Intraparenchymal Meningioma in a Child. Neurol Med Chir (Tokyo) 2011; 51: 793-797. http://dx.doi.org/10.2176/nmc.51.793

[78] Wada T, Suzuki M, Beppu T, Arai H, Yoshida Y, Ogawa A, et al. A case of subcortical meningioma. Acta (Wien) 2000; 142: 209-213.

http://dx.doi.org/10.1007/s007010050026
[79] Sano K, Wakai S, Ochiai C, Takakura K. Characteristics of intracranial meningiomas in childhood. Childs Brain 1981; 8(2): 98-106.

[80] Schroeder BA, Samaraweera RN, Starshak RJ, Oechler HW. Intraparenchymal meningioma in a child: CT and MR findings. J Comput Assist Tomogr 1987; 11: 192-193. http://dx.doi.org/10.1097/00004728-198701000-00046

[81] Kimura H, Nakagawa A, Sakaki S, Matsuoka K. Intracranial meningioma of an infant: a case report. No Shinkei Geka 1987; 15: 663-668.

[82] Mamourian AC, Lewandowski AE, Towfighi J. Cystic intraparenchymal meningioma in a child: case report. AJNR Am J Neuroradiol 1991; 12: 366-367.

[83] Matsumoto M, Nakazawa K, Hashimoto T, Nakamura N. A case of meningioma in a child associated with focal motor seizure. Shoni No Noshinkei 1992; 17: 285-288.

[84] Kaneko F, Sasaki K, Kobayashi T. Intra-axial meningioma in childhood-case report. Tokushima Shimin Byoin Igaku Zasshi 1993; 7: 131-134.

[85] Miwa Y, Uemura, Takada M, Funaoka T, Yamada H. A case of singular meningioma in a child; in Proceedings of the 10th Congress of Japanese Pediatric Neurosurgery 1996, cited in 21.

[86] Teo JG, Goh KY, Rosenblum MK, Muszynski CA, Epstein FJ. Intraparenchymal clear cell meningioma of the brainstem in a 2-year-old child. Case report and literature review. Pediatr Neurosurg 1998; 28: 27-30. http://dx.doi.org/10.1159/000028614

[87] Karadereler S, Aker F, Berkman Z. Intraparenchymal meningioma in a child. Case report and review of the literature. J Neurosurg 2004; 101(1 Suppl): 112-115.

[88] Zhang J, Chi LY, Meng B, Li F, Zhu SG. Meningioma without dural attachment: case report, classification, and review of the literature. Surg Neurol 2007; 67: 535-539. http://dx.doi.org/10.1016/j.surneu.2006.07.011

[89] Kepes JJ, Chen WY-K, Connors MH, Vogel FS. "Chordoid" meningeal tumors in young individuals with peritumoral lymphoplasmocellular infiltrates causing systemic manifestations of the Castleman syndrome. A report of seven cases. Cancer 1988; 62: 391-406.

http://dx.doi.org/10.1002/10970142(19880715)62:2<391::AIDCNCR2820620226>3.0.CO;2-7

[90] Epari S, Sharma MC, Sarkar C, Garg A, Gupta A, Mehta VS. Chordoid meningioma, an uncommon variant of meningioma: a clinicopathologic study of 12 cases. J Neurooncol 2006; 78 : 263-269. http://dx.doi.org/10.1007/s11060-005-9092-y

[91] Kobata H, Kondo A, Iwasaki K, Kusaka H, Ito H, Sawada S. Chordoid meningioma in a child. Case report. J Neurosurg 1998; 88: 319-323.

http://dx.doi.org/10.3171/jns.1998.88.2.0319

[92] Kleihues P, Louis DN, Scheithauer BW, Rorke LB, Reifenberger G, Burger PC, et al. The WHO classification of tumors of the nervous system. J Neuropathol Exp Neurol 2002; 61: 215-225.

[93] Kleihues P, Burger PC, Scheithauer BW. Histological typind of tumours of the central nervous system, 2nd edn. Berlin, Springer, 1993. http://dx.doi.org/10.1007/978-3-642-84988-6

[94] Kleihues P, Burger PC, Scheithauer BW. The new WHO classification of brain tumours. Brain Pathol 1993; 3: 255268.

http://dx.doi.org/10.1111/j.1750-3639.1993.tb00752.x

[95] Marhx-Bracho A, Rueda-Franco F, Ibarra-de la Torre A, García-González O, Bornstein-Quevedo L, de León-Bogorge B. Chordoid meningioma of the foramen magnum in a child: 
a case report and review of the literature. Childs Nerv Syst 2008; 24: 623-627.

http://dx.doi.org/10.1007/s00381-007-0568-2

[96] Song KS, Park SH, Cho BK, Wang KC, Phi JH, Kim SK. Third ventricular chordoid meningioma in a child. $\mathrm{J}$ Neurosurg Pediatr 2008; 2(4): 269-72. http://dx.doi.org/10.3171/PED.2008.2.10.269

[97] Gold DG, Neglia JP, Dusenbery KE. Second neoplasms after megavoltage radiation for paediatric tumours. Cancer 2003; 97: 2588-2596.

http://dx.doi.org/10.1002/cncr.11356

[98] Moss SD, Rockswold G, Chou SN, Yock D, Berger MS. Radiation-induced meningiomas in paediatric patients. Neurosurgery 1988; 22: 758-761. http://dx.doi.org/10.1227/00006123-198804000-00026

[99] Rusyniak WG, Marchese MJ, Nelson CN. Benign meningioma with a short latency period following irradiation. Surg Neurol 1992; 38: 261-264. http://dx.doi.org/10.1016/0090-3019(92)90036-M

[100] Bliss P, Kerr GR, Gregor A. Incidence of second brain tumors after pituitary irradiation in Edinburgh 1962-1990. Clin Oncol 1994; 6: 361-363.

http://dx.doi.org/10.1016/S0936-6555(05)80187-6

[101] Kano T, Zama A, Ono N, Nakamura T, Tamura M, Ohe T, et al. A juvenile case of radiation induced meningioma two years after radiation for craniopharyngioma. No Shinkei Geka 1994; 22: 367-370.

[102] Mack EE, Wilson CB. Meningiomas induced by high-dose cranial irradiation. J Neurosurrg 1993; 79: 28-31. http://dx.doi.org/10.3171/jns.1993.79.1.0028

[103] Starshak RJ. Radiation-induced meningioma in children: report of two cases and review of literature. Pediatr Radiol 1996; 26: 537-541.

http://dx.doi.org/10.1007/BF01372237

[104] Duffner PK, Krischer JP, Horowitz ME, Cohen ME, Burger $\mathrm{PC}$, Friedman $\mathrm{HS}$, et al. Second malignancies in young children with primary brain tumors following treatment with prolonged postoperative chemotherapy and delayed irradiation: a Pediatric Oncology Group study. Ann Neurol 1998; 44: 313-316. http://dx.doi.org/10.1002/ana.410440305

[105] Caroli E, Salvati M, Roperto R, D'Andrea G, Ferrante L. High-dose radiation-induced meningioma in children - case report and critical review of the literature. Zentralbl Neurochir 2005; 66(1): 39-42. http://dx.doi.org/10.1055/s-2004-832472

[106] Choudhary A, Pradhan S, Huda MF, Mohanty S, Kumar M. Radiation induced meningioma with a short latent period following high dose cranial irradiation - case report and literature review. J Neurooncol 2006; 77(1): 73-7. Epub 2005 Nov 15. http://dx.doi.org/10.1007/s11060-005-9009-9

[107] Freudenstein D, Bornemann A, Ernemann U. Intracranial malignant B-cell lymphoma of the dura. Clin Neuropathol 2000; 19: 34-37.

[108] Katz S, J. Rootman, R. Goldberg. Secondary and metastatic tumors of the orbit. Duane's ophthalmology, Philadelphia, Lippincott Williams \& Wilkins, 2007.
[109] Brown DC, Gatter KC: Ki-67 protein: The immaculate deception? Histopathology 2002; 40: 2-11. http://dx.doi.org/10.1046/.1365-2559.2002.01343.x

[110] Kolles H, Niedermayer I, Schmitt C, Henn W, Feld R, Steudel $\mathrm{WI}$, et al. Triple approach for diagnosis and grading of meningiomas: Histology, morphometry of Ki-67/Feulgen stainings, and cytogenetics. W Acta Neurochir (Wien) 1995 137: 174-181. http://dx.doi.org/10.1007/BF02187190

[111] Karamitopoulou E, Perentes E, Tolnay M, Probst A. Prognostic significance of MIB-1, p53 and bcl-2 immunoreactivity in meningiomas. Hum Pathol 1998; 291: 140-145.

http://dx.doi.org/10.1016/S0046-8177(98)90224-6

[112] Lanzafame S, Torrisi A, Barbagallo G, Emmanuele C, Alberio $\mathrm{N}$, Albanese V. Correlation between histological grade, MIB$1, \mathrm{p} 53$, and recurrence in 69 completely resected primary intracranial meningiomas with a 6 year mean follow-up. Pathol Res Pract 2000; 196: 483-438. http://dx.doi.org/10.1016/S0344-0338(00)80050-3

[113] Perry A, Stafford SL, Scheithauer BW, Suman VJ, Lohse $\mathrm{CM}$. The prognostic signifi cance of MIB-1, p53, and DNA fl ow cytometry in completely resected primary meningiomas. Cancer 1998; 82: 2262-69. http://dx.doi.org/10.1002/(SICl)10970142(19980601)82:11<2262::AID-CNCR23>3.0.CO;2-R

[114] Matsuno A, Fujimaki T, Sasaki T, Nagashima T, Ide T, Asai $A$, et al. Clinical and histopathological analysis of proliferative potentials of recurrent and non-recurrent meningiomas. Acta Neuropathol 1996; 91: 504-510. http://dx.doi.org/10.1007/s004010050458

[115] Nakasu S, Li DH, Okabe H, Nakajima M, Matsuda M. Significance of MIB-1 staining incides in meningiomas. Comprasion of two couting methods. Am J Surg Pathol 2001; 25(4): $472-478$ http://dx.doi.org/10.1097/00000478-200104000-00006

[116] Maier H, Wanschitz J, Sedivy R, Rössler K, Ofner D, Budka $\mathrm{H}$. Proliferation and DNA fragmentation in meningioma subtypes. Neuropathol Appl Neurobiol 1997; 23(6): 496-506. http://dx.doi.org/10.1111/j.1365-2990.1997.tb01327.x

[117] Perry A, Scheithauer BW, Stafford SL, Lohse CM, Wollan PC. "Malgnancy" in meningiomas: a clinicopathologic study of 116 patients, with grading implications. Cancer 1999; 85(9): 2046-2056.

http://dx.doi.org/10.1002/(SICI)10970142(19990501)85:9<2046::AID-CNCR23>3.0.CO;2-M

[118] Perry A, Stafford SL, Scheithauer BW, Suman VJ, Lohse $\mathrm{CM}$. Meningioma grading: an analysis of histologic parameters. Am J Surg Pathol 1997; 21(12): 1455-65. http://dx.doi.org/10.1097/00000478-199712000-00008

[119] Ragel B, Jensen R. Pathophysiology of meningiomas. Sem Neurosurg 2003; 14: 169-186. http://dx.doi.org/10.1055/s-2004-817734

[120] Couce ME, Aker FV, Scheithauer BW. Chordoid Meningioma: A Clinicopathologic Study of 42 Cases. The American Journal of Surgical Pathology 2000; 24(7): 899905.

http://dx.doi.org/10.1097/00000478-200007000-00001

\section{DOI: http://dx.doi.org/10.6000/1929-2279.2014.03.01.4}

(c) 2014 Efendioglu et al.; Licensee Lifescience Global.

This is an open access article licensed under the terms of the Creative Commons Attribution Non-Commercial License (http://creativecommons.org/licenses/by-nc/3.0/) which permits unrestricted, non-commercial use, distribution and reproduction in any medium, provided the work is properly cited. 